\title{
ANALISA DAN PEMETAAN TOTAL PADATAN TERLARUT DI PESISIR PANTAI PASURUAN DENGAN CITRA SATELIT TERRA MODIS
}

\author{
Muhammad Fahmi Izzatur Rahman ${ }^{(1)}$, Hendrata Wibisana ${ }^{(2)}$ Siti Zainab ${ }^{(2)}$ \\ ${ }^{1}$ Alumni Teknik Sipil Universitas Pembangunan Nasional "Veteran" Jawa Timur \\ ${ }^{2}$ Departemen Teknik Sipil Universitas Pembangunan Nasional "Veteran” Jawa Timur \\ Email: hendrata2008@gmail.com
}

\begin{abstract}
ABSTRAK
Kota Pasuruan berada di jalur utama pantai utara yang menghubungkan Pulau Jawa dengan Pulau Madura yang menjadikannya sebagai kota dengan prospek ekonomi yang besar di kawasan Indonesia bagian Timur. Total Dissolved Solid (TDS) mengandung berbagai zat terlarut (baik itu zat organik, anorganik, atau material lainnya) yang terlarut dalam air dan kadar TDS mempengaruhi kekeruhan air sehingga jika terlalu tinggi akan mengganggu biota laut dan dapat menyebabkan sedimentasi. Berdasarkan latar belakang tersebut, diperlukan usaha untuk memantau persebaran Total Dissolved Solid (TDS) di pesisir pantai Pasuruan dengan menggunakan citra satelit Terra MODIS dan juga pengambilan sampel di lapangan langsung yaitu di pesisir pantai Kota Pasuruan, Hasil penelitian ini dapat disimpulkan bahwa citra satelit Terra MODIS panjang gelombang $667 \mathrm{~nm}$ dengan model Algoritma Logarithmic $\mathrm{TDS}(\mathrm{mg} / \mathrm{l})=\mathbf{- 2 5 4 8} \ln (\mathbf{x}) \mathbf{- 1 2 2 6 0}$ dapat digunakan untuk menghitung kadar TDS dikarenakan hasil dari uji korelasi memenuhi syarat 0,61 maka dari itu penelitian ini diharapkan dapat membantu dalam memetakan sebaran Total Dissolved Solid (TDS) dan juga untuk memantau kenaikan maupun penurunan Total Dissolved Solid (TDS) sehingga dapat memberi solusi yang tepat dalam pengambilan keputusan.
\end{abstract}

Kata Kunci: Total Dissolved Solid (TDS), Terra MODIS, Pemetaan, Pasuruan.

\begin{abstract}
Pasuruan City is located on the main line of the north coast that connects Java to Madura which makes it a city with a large economic outlook in the eastern region of Indonesia. Total Dissolved Solid (TDS) contains a variety of solutes (whether organic, inorganic, or other materials) that are dissolved in water and TDS rates affect the turbidity of water so that if it is too high it will disrupt the marine life and may cause sedimentation. Based on the background, it is necessary to monitor the spread of Total Dissolved Solid (TDS) on the coast of Pasuruan by using Terra MODIS satellite imagery and also on-the-ground sampling at the coastal city of Pasuruan. The results of this study can be concluded that the satellite imagery of Terra MODIS $667 \mathrm{~nm}$ wavelength with Logarithmic algorithm model TDS $(\mathrm{mg} / \mathrm{l})=-\mathbf{2 5 4 8} \ln (\boldsymbol{x})-12260$ can be used to calculate TDS rate because the result of the correlation test is qualified 0.61 then the research is expected to be helpful in mapping the spread of Total Dissolved Solid (TDS) and also to monitor the rate of Total Dissolved Solid (TDS) so as to provide the right solution in decision making.
\end{abstract}

Keyword: Total Dissolved Solid (TDS), Terra MODIS, Mapping, Pasuruan District.

\section{PENDAHULUAN}

\subsection{Latar Belakang}

Kota Pasuruan merupakan wilayah administrasi yang mempunyai luas wilayah sebesar 35,29 $\mathrm{km}^{2}$. Dari total luas wilayah Kota Pasuruan, sekitar 65,85\% adalah luas kawasan terbangun dan luas ruang terbuka merupakan sisa dari kawasan terbangun yaitu sebesar 34,15\% dari luas wilayah administrasi (RKPD Kota Pasuruan, 2014). Seluruh 
wilayah Kota Pasuruan berbatasan dengan Kabupaten Pasuruan. Pasuruan berada di jalur utama pantai utara yang menghubungkan Pulau Jawa dengan Pulau Madura yang menjadikannya sebagai kota dengan prospek ekonomi yang besar di kawasan Indonesia bagian Timur.

Total Dissolved Solid (TDS) mengandung berbagai zat terlarut (baik itu zat organik, anorganik, atau material lainnya) dengan diameter $<10,3 \mu \mathrm{m}$ yang terdapat pada sebuah larutan yang terlarut dalam air (Brando et al., 2006; Carlson, 2014; Ratnaningsih et al., n.d.). Padatan terlarut termasuk salah satu faktor penyebab kekeruhan di air (Wibisana et al., 2019; Wibisana \& Zainab, 2017). Semakin tinggi kadar padatan terlarut yang ada di air maka semakin keruh air tersebut. Apabila tingkat padatan terlarut di laut sangat tinggi akan menyebabkan air laut menjadi keruh. Air laut yang keruh menghalangi masuknya cahaya matahari yang dibutuhkan oleh tanaman dan organisme hidup di dasar laut sehingga dapat mengurangi populasinya karena kekurangan cahaya matahari (Bilotta \& Brazier, 2008; Crisci et al., 2017; Ody et al., 2016).

Alasan dilakukan penelitian ini karena dirasa perlunya usaha untuk mengetahui persebaran Total Dissolved Solid (TDS) di pesisir pantai Pasuruan sehingga dapat memantau tingkat kadar Total Dissolved Solid (TDS) yang mempengaruhi kekeruhan air laut.

\subsection{Rumusan Masalah}

Perumusan masalah yang akan dibahas dalam penelitian ini adalah:

1. Bagaimana permodelan algoritma empiris yang sesuai dengan Total Dissolved Solid (TDS) di pesisir pantai Pasuruan?

2. Bagaimana sebaran nilai konsentrasi Total Dissolved Solid (TDS) di pesisir pantai Pasuruan?

3. Bagaimana peta tematik sebaran Total Dissolved Solid (TDS) di pesisir pantai Pasuruan?

\subsection{Tujuan Penelitian}

Tujuan dari penelitian ini adalah:

1. Menghitung permodelan algoritma empiris yang sesuai dengan Total Dissolved Solid (TDS) di pesisir pantai Pasuruan.

2. Menghitung sebaran nilai konsentrasi Total Dissolved Solid (TDS) di pesisir pantai Pasuruan. 
3. Membuat peta tematik sebaran Total Dissolved Solid (TDS) di pesisir pantai Pasuruan.

\subsection{Batasan Masalah}

1. Lokasi penelitian dilakukan di pesisir pantai Pasuruan pada koordinat $112^{\circ} 52^{\prime} 33.54^{\prime \prime E}-113^{\circ} 6^{\prime} 10.18^{\prime \prime E}$ bujur timur dan 7³4'22.86"S - 742'6.53"S lintang selatan.

2. Analisa Total Dissolved Solid (TDS) dilakukan menggunakan citra satelit Terra MODIS.

3. Hanya menentukan nilai konsentrasi Total Dissolved Solid (TDS) tidak termasuk Total Suspended Solid (TSS).

\subsection{Lokasi Penelitian}

Batasan lokasi penelitian seperti pada Gambar 1.

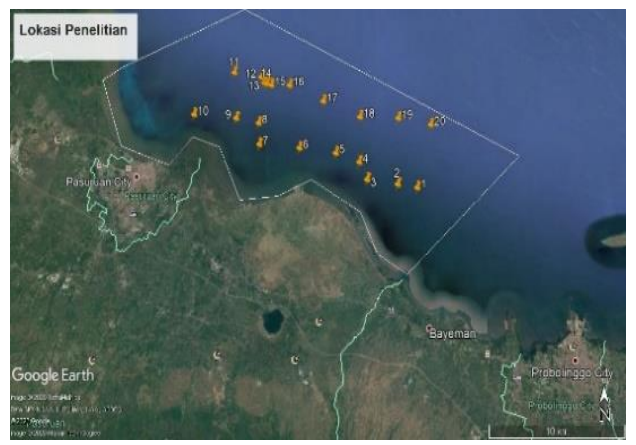

Gambar 1 Batasan Lokasi Penelitian

\section{TINJAUAN PUSTAKA}

\subsection{Pesisir dan Pantai}

Menurut Triatmodjo, B (2008), ada dua istilah tentang kepantaian dalam Bahasa Indonesia yang sering rancu pemakaiannya, yaitu pesisir (coast) dan pantai (shore). Pesisir adalah daerah darat di tepi laut yang masih mendapat pengaruh laut seperti pasang surut, angin laut, dan perembesan air laut. Sedangkan pantai adalah daerah tepi perairan yang dipengaruhi oleh air pasang tertinggi dan air surut terendah.

\subsection{Total Dissolved Solid (TDS)}

Total Dissolved Solid (TDS) adalah jumlah zat padat terlarut baik berupa ion-ion organik, senyawa, maupun koloid didalam air (WHO, 2003). 
Penyebab utama terjadinya peningkatan Total Dissolved Solid (TDS) adalah bahan anorganik berupa ion-ion yang umum dijumpai di perairan. Benda-benda padat di dalam air tersebut berasal dari banyak sumber, organik seperti daun, lumpur, plankton serta limbah industri dan kotoran. Sumber lainnya bisa berasal dan limbah rumah tangga, pestisida, dan banyak lainnya. Sedangkan sumber anorganik berasal dari batuan dan udara yang mengandung kasium bikarbonat, nitrogen, besi fosfor, sulfur, dan mineral lain.

Perubahan dalam konsentrasi TDS dapat berbahaya karena akan menyebabkan perubahan salinitas, perubahan komposisi ion-ion, perubahan kekeruhan dan kejernihan air laut, dan toksisitas masing-masing ion. Kekeruhan atau turbidity adalah ukuran kejernihan relatif cairan. Kekeruhan adalah karakteristik optik air dan merupakan ekspresi dari jumlah cahaya yang tersebar oleh materi di dalam air ketika cahaya bersinar melalui sampel air.

Padatan terlarut termasuk salah satu faktor penyebab kekeruhan di air. Semakin tinggi kadar padatan terlarut yang ada di air maka semakin keruh air tersebut. Apabila tingkat padatan terlarut di laut tinggi akan menyebabkan air laut menjadi keruh. Air laut yang keruh menghalangi masuknya cahaya matahari yang dibutuhkan oleh tanaman dan organisme hidup di dasar laut sehingga dapat mengurangi populasinya karena kekurangan cahaya matahari.

\subsection{Citra Satelit Terra MODIS}

MODIS (Moderate Resolution Imaging Spectroradiometer) merupakan instrumen yang beroperasi pada satelit Terra. Satelit ini memiliki lebar sapuan sebesar $2330 \mathrm{~km}$ dan memotret seluruh permukaan bumi dalam satu atau dua hari. Data Terra-MODIS dimanfaatkan untuk pemanfaatan fase tanaman padi, zona potensi penangkapan ikan, monitoring titik api kebakaran hutan, dll.

MODIS ideal untuk memantau perubahan skala besar di biosfer yang menghasilkan wawasan baru tentang cara kerja siklus karbon global. MODIS mengukur aktivitas fotosintesis tanaman darat dan laut (fitoplankton) untuk menghasilkan perkiraan yang lebih baik tentang berapa banyak gas rumah kaca yang diserap dan digunakan dalam produktivitas tanaman. Digabungkan dengan pengukuran suhu permukaan sensor, pengukuran biosfer MODIS membantu para ilmuwan melacak sumber dan tenggelamnya karbon dioksida dalam menanggapi perubahan iklim. 


\section{METODOLOGI PENELITIAN}

Gambar 2 adalah diagram alir penelitian dan Gambar 3 adalah diagram alir dari pengolahan data (SIG).

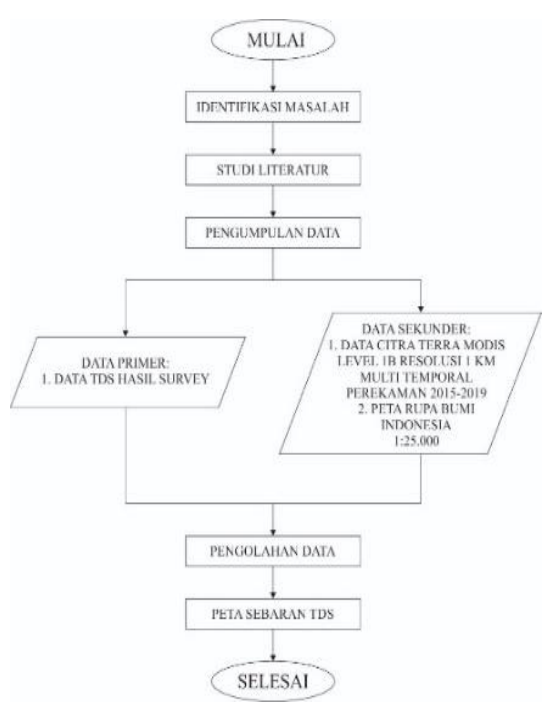

Gambar 2 Diagram Alir penelitian

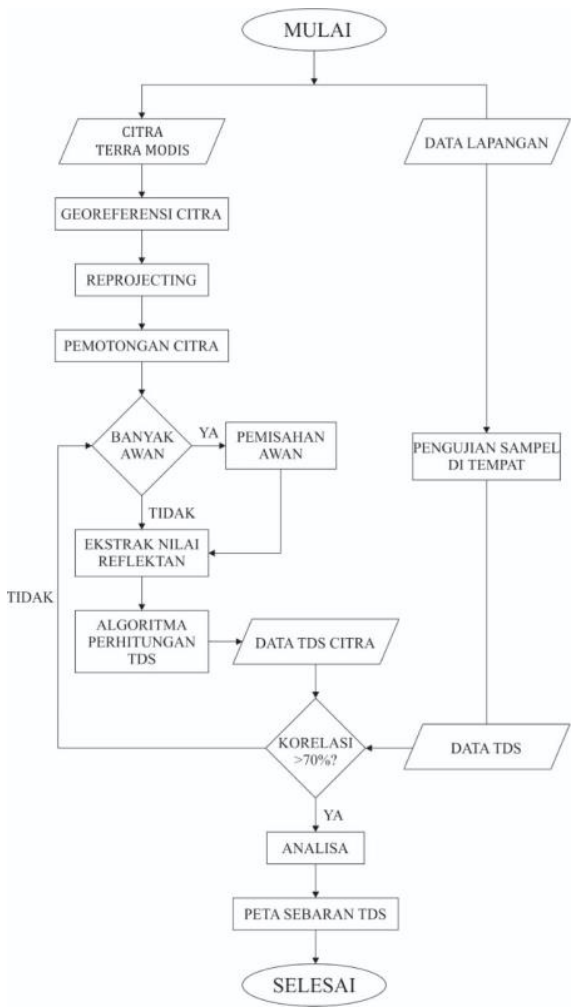

Gambar 3 Diagram Alir Pengolahan Data (SIG)

\subsection{Lokasi Penelitian}

Pasuruan terbagi menjadi dua wilayah administratif yaitu bagian kota dan kabupaten. Lokasi penelitian dilaksanakan di bagian Kota dan juga Kabupaten. Seluruh wilayah Kota Pasuruan berbatasan dengan Kabupaten Pasuruan.

Pengambilan sampel dilaksanan pada tanggal 6 Maret 2020 dengan personil empat orang termasuk penulis dan juga dua orang dari kepolisian. Pengambilan sampel meghasilkan 20 titik koordinat.

\subsection{Data Citra Satelit Terra MODIS}

Peta citra satelit Terra MODIS yang digunakan dalam penelitian ini diperoleh dari laman website EOS-Data https://oceandata.sci.gsfc.nasa.gov/MODIS- Terra/ adalah peta level 2 dengan nama filenya T2020066032000.L2_LAC_OC.nc (Esaias, 1996; NASA Goddard Space Flight Center, Ocean Ecology Laboratory, 2020). 


\subsection{Kadar Total Dissolved Solid (TDS)}

Pada penelitian ini sampel akan langsung diukur di tempat saat pengambilan di laut di setiap titik koordinat, dengan menggunakan alat ukur TDS-3 yang dapat mengukur kadar TDS dan juga suhu. Pengambilan sampel dilakukan pada tanggal 6 Maret 2020 tepatnya dimulai pukul 08.30 WIB. Hasil pengambilan sampel terdapat pada Tabel 1.

Tabel 1 Hasil Pengukuran Kadar TDS-insitu (mg/l)

\begin{tabular}{|c|c|c|c|c|c|c|c|}
\hline \multirow[b]{2}{*}{ Titik } & \multicolumn{2}{|c|}{ Koordinat } & \multirow{2}{*}{$\begin{array}{c}\text { TDS } \\
\text { Insitu } \\
\text { (mg/l) }\end{array}$} & \multirow[b]{2}{*}{ Titik } & \multicolumn{2}{|c|}{ Koordinat } & \multirow{2}{*}{$\begin{array}{c}\text { TDS } \\
\text { Insitu } \\
\text { (mg/l) }\end{array}$} \\
\hline & Latitude & Longitude & & & Latitude & Longitude & \\
\hline 1 & $7^{\circ} 38^{\prime} 59^{\prime \prime} \mathrm{S}$ & $113^{\circ} 6^{\prime} 39^{\prime \prime} \mathrm{E}$ & 4430 & 11 & $7^{\circ} 34^{\prime} 17^{\prime \prime S}$ & $112^{\circ} 58^{\prime} 29 " \mathrm{E}$ & 5930 \\
\hline 2 & $7^{\circ} 38^{\prime} 51 " \mathrm{~S}$ & $113^{\circ} 5^{\prime} 48^{\prime \prime} \mathrm{E}$ & 3430 & 12 & $7^{\circ} 34^{\prime} 29^{\prime \prime S}$ & $112^{\circ} 59^{\prime} 43^{\prime \prime E}$ & 6550 \\
\hline 3 & $7^{\circ} 38^{\prime} 40^{\prime \prime} \mathrm{S}$ & $113^{\circ} 4^{\prime} 28^{\prime \prime E}$ & 3340 & 13 & $7^{\circ} 34^{\prime} 44^{\prime \prime S}$ & $112^{\circ} 59^{\prime} 52^{\prime \prime E}$ & 7450 \\
\hline 4 & $7^{\circ} 37^{\prime} 59 " \mathrm{~S}$ & $113^{\circ} 4^{\prime} 8^{\prime \prime E}$ & 4010 & 14 & $7^{\circ} 34^{\prime} 46^{\prime \prime} \mathrm{S}$ & $112^{\circ} 59^{\prime} 59^{\prime \prime E}$ & 7540 \\
\hline 5 & $7^{\circ} 37^{\prime} 37^{\prime \prime} \mathrm{S}$ & $113^{\circ} 3^{\prime} 6^{\prime \prime} \mathrm{E}$ & 4290 & 15 & $7^{\circ} 34^{\prime} 49^{\prime \prime} \mathrm{S}$ & $113^{\circ} 0^{\prime} 11 " \mathrm{E}$ & 7540 \\
\hline 6 & $7^{\circ} 37^{\prime} 25^{\prime \prime} \mathrm{S}$ & $113^{\circ} 1 ' 29^{\prime \prime E}$ & 6280 & 16 & $7^{\circ} 34^{\prime} 50^{\prime \prime} \mathrm{S}$ & $113^{\circ} 1^{\prime} 1 " \mathrm{E}$ & 7520 \\
\hline 7 & $7^{\circ} 37^{\prime} 16^{\prime \prime S}$ & $112^{\circ} 59^{\prime} 42^{\prime \prime} \mathrm{E}$ & 6410 & 17 & $7^{\circ} 35^{\prime} 30^{\prime \prime} \mathrm{S}$ & $113^{\circ} 2^{\prime} 33^{\prime \prime E}$ & 7890 \\
\hline 8 & $7^{\circ} 36^{\prime} 24^{\prime \prime S}$ & $112^{\circ} 59^{\prime} 39^{\prime \prime} \mathrm{E}$ & 6290 & 18 & $7^{\circ} 36^{\prime} 9^{\prime \prime S}$ & $113^{\circ} 4^{\prime} 12^{\prime \prime E}$ & 4570 \\
\hline 9 & $7^{\circ} 36^{\prime} 12^{\prime \prime} \mathrm{S}$ & $112^{\circ} 58^{\prime} 38^{\prime \prime E}$ & 4790 & 19 & $7^{\circ} 36^{\prime} 12^{\prime \prime} \mathrm{S}$ & $113^{\circ} 5^{\prime} 55^{\prime \prime E}$ & 4770 \\
\hline 10 & $7^{\circ} 36^{\prime} 3 " \mathrm{~S}$ & $112^{\circ} 56^{\prime} 44^{\prime \prime} \mathrm{E}$ & 3420 & 20 & $7^{\circ} 36^{\prime} 28^{\prime \prime S}$ & $113^{\circ} 7^{\prime 22}=\mathrm{E}$ & 5180 \\
\hline
\end{tabular}

Sumber: Hasil Survey Lapangan

\section{HASIL DAN PEMBAHASAN}

\subsection{Pengolahan Data Citra Satelit}

Pengolahan data citra satelit Terra MODIS dihitung menggunakan permodelan algoritma. Dimana untuk mendapatkan nilai reflektan, harus memilih gelombang elektromagnetik untuk diolah. Adapun gelombang yang dipilih yaitu $412 \mathrm{~nm}$ (warna biru), $531 \mathrm{~nm}$ (warna hijau), dan $667 \mathrm{~nm}$ (warna merah).

Nilai reflektan didapat dengan cara masuk ke pin manager dan pilih filter pixel data, setelah itu pilih band Rrs 412, Rrs 531, dan Rrs 667 nm kemudian akan muncul nilai reflektannya.

Setelah mendapatkan nilai reflektan dari masing-masing gelombang citra satelit yaitu $412 \mathrm{~nm}$ (warna biru), $531 \mathrm{~nm}$ (warna hijau), dan $667 \mathrm{~nm}$ (warna merah) dilakukan analisa data dengan Microsoft Excel. Data yang dipakai untuk analisa adalah 15 data (titik 1 sampai dengan titik 15) dan sisanya 5 data (titik 16 sampai 20) digunakan untuk validasi data. Nilai reflektan sebagai parameter sumbu X dan kadar TDS insitu sebagai sumbu Y. Ditentukan empat persamaan yaitu Linear, Exponential, Logarithmic, dan Power untuk mendapatkan nilai derajat determinasi $\mathrm{R}^{2}$ terbesar. 
Tabel 2 Hasil Ekstrak Nilai Reflektan Citra Terra MODIS

\begin{tabular}{cccccccc}
\hline Titik & Rrs_412 & Rrs_531 & Rrs_645 & Titik & Rrs_412 & Rrs_531 & Rrs_645 \\
\hline 1 & 0.00376 & 0.00595 & 0.00094 & 11 & 0.00326 & 0.00471 & 0.00097 \\
2 & 0.00331 & 0.00559 & 0.00081 & 12 & 0.00368 & 0.00433 & 0.00062 \\
3 & 0.00373 & 0.00642 & 0.00144 & 13 & 0.00368 & 0.00433 & 0.00062 \\
4 & 0.00413 & 0.00628 & 0.00123 & 14 & 0.00411 & 0.00424 & 0.00046 \\
5 & 0.00445 & 0.00686 & 0.00161 & 15 & 0.00373 & 0.00438 & 0.00053 \\
6 & 0.00385 & 0.00574 & 0.00105 & 16 & 0.00376 & 0.00347 & 0.00003 \\
7 & 0.00195 & 0.00488 & 0.00142 & 17 & 0.00360 & 0.00374 & 0.00009 \\
8 & 0.00244 & 0.00417 & 0.00072 & 18 & 0.00333 & 0.00465 & 0.00049 \\
9 & 0.00108 & 0.00448 & 0.00316 & 19 & 0.00310 & 0.00530 & 0.00089 \\
10 & 0.00220 & 0.00540 & 0.00177 & 20 & 0.00352 & 0.00533 & 0.00088 \\
\hline
\end{tabular}

Sumber: Hasil Olah Data

\subsection{Pengolahan Data Citra Rrs_412 (Biru)}

Data yang ada diolah hingga membentuk grafik scatter dimana nantinya akan menunjukkan nilai korelasi $\mathrm{R}$ dari masing-masing model matematis yang ada, seperti yang terlihat pada Gambar 4 sampai dengan Gambar 7.

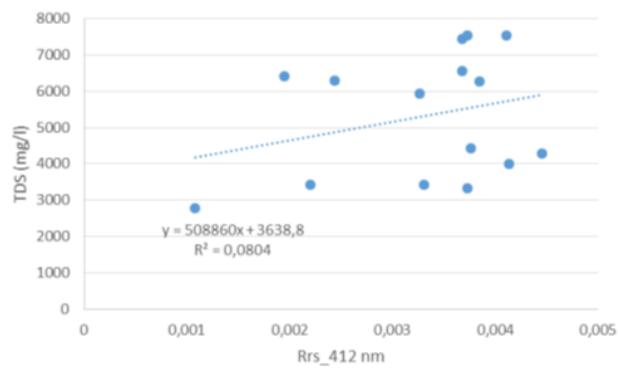

Gambar 3 Model Matematis Linier untuk Rrs_412 nm

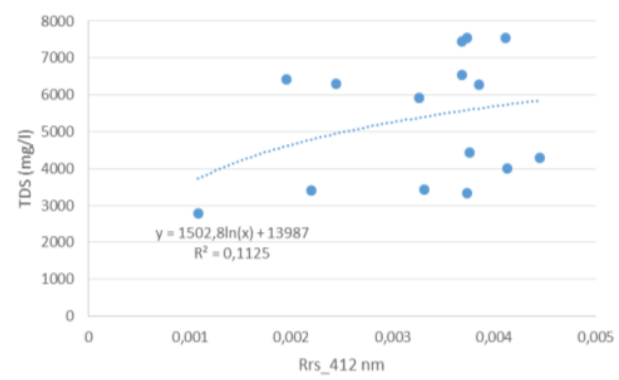

Gambar 5 Model Matematis Logaritmik untuk Rrs_412 nm

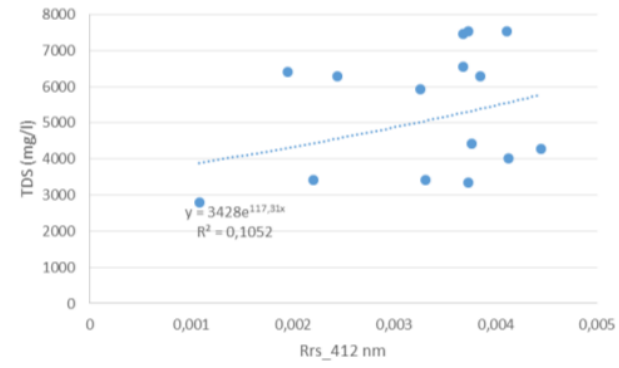

Gambar 4 Model Matematis Eksponensial untuk Rrs_412 nm

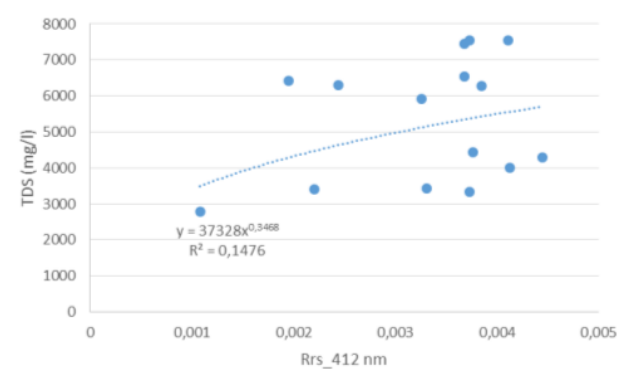

Gambar 6 Model Matematis Power untuk Rrs_412 nm 


\subsection{Pengolahan Data Citra Rrs_531 (Hijau)}

Data yang ada diolah hingga membentuk grafik scatter dimana nantinya akan menunjukkan nilai korelasi $\mathrm{R}$ dari masing-masing model matematis yang ada, seperti yang terlihat pada Gambar 8 sampai dengan Gambar 11.

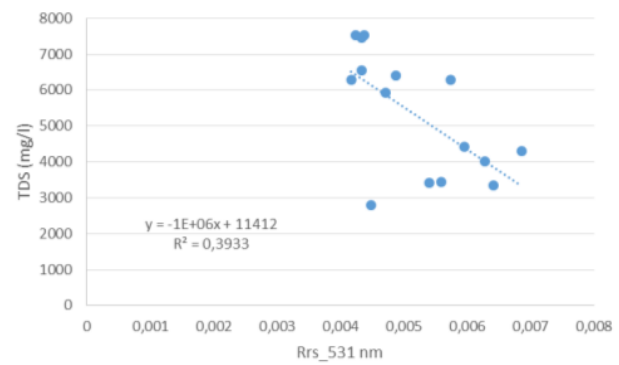

Gambar 8 Model Matematis Linier untuk Rrs_531 nm

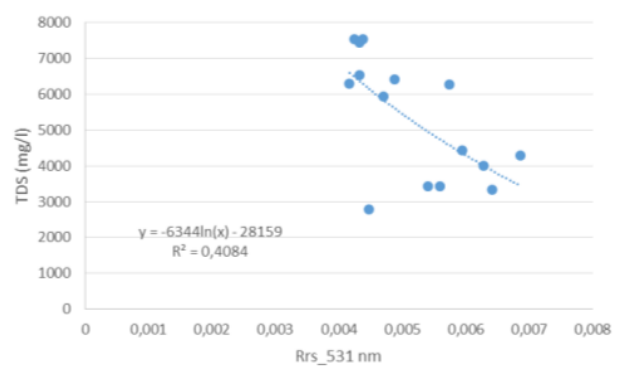

Gambar 10 Model Matematis Logaritmik untuk Rrs_513 nm

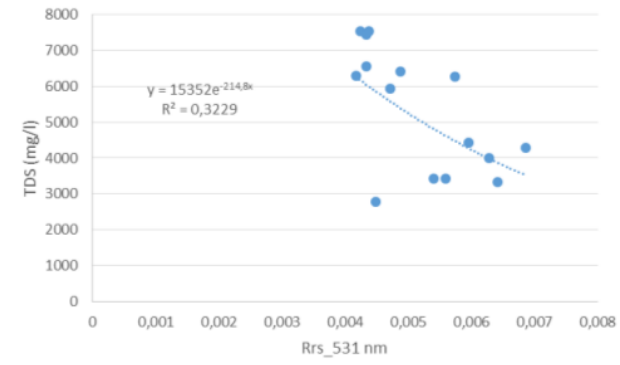

Gambar 9 Model Matematis Eksponensial untuk Rrs_531 nm

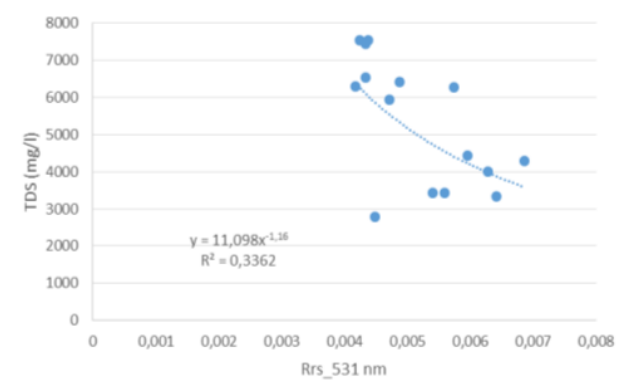

Gambar 11 Model Matematis Power untuk Rrs_531 nm

\subsection{Pengolahan Data Citra Rrs_667 (Merah)}

Data yang ada diolah hingga membentuk grafik scatter dimana nantinya akan menunjukkan nilai korelasi $\mathrm{R}$ dari masing-masing model matematis yang ada, seperti yang terlihat pada Gambar 12 sampai dengan Gambar 15.

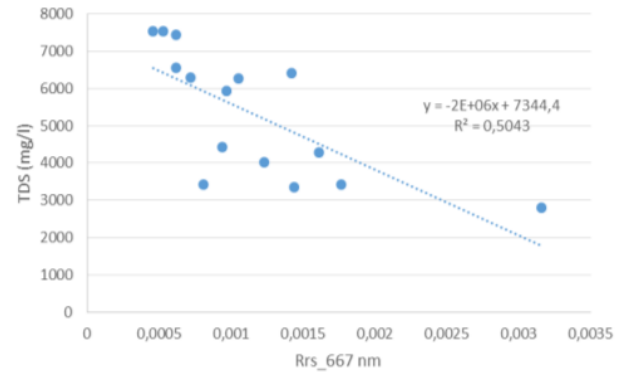

Gambar 12 Model Matematis Linier untuk Rrs_667 nm

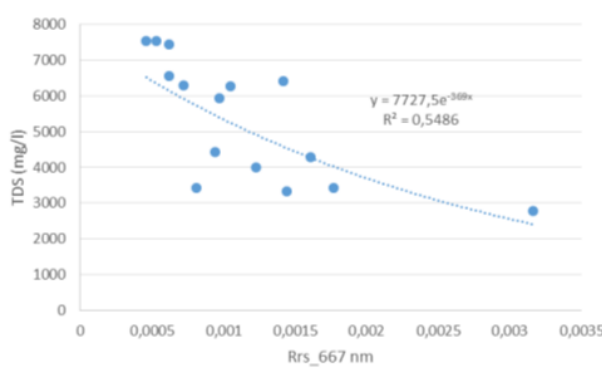

Gambar 13 Model Matematis Eksponensial untuk Rrs_667 nm 


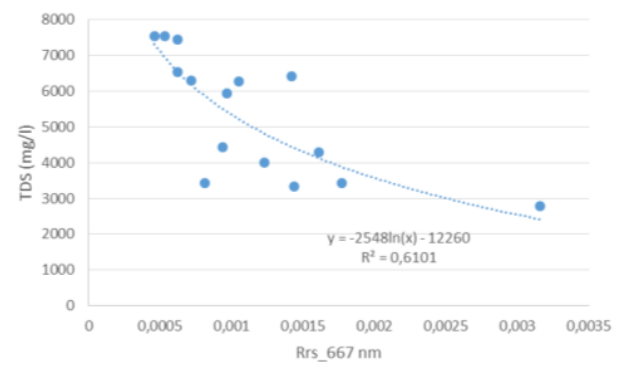

Gambar 14 Model Matematis Logaritmik untuk Rrs_667 nm

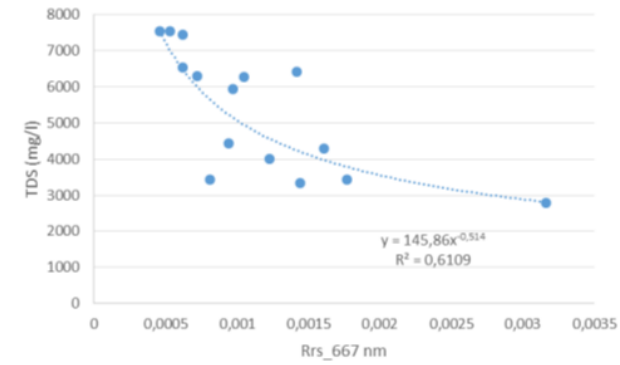

Gambar 15 Model Matematis Power untuk Rrs_667 nm

\subsection{Perhitungan Kadar TDS Citra Satelit}

Dari semua persamaan yang telah dilakukan pada nilai reflektan panjang gelombang citra Terra MODIS untuk $412 \mathrm{~nm}$ (warna biru), $531 \mathrm{~nm}$ (warna hijau), dan $667 \mathrm{~nm}$ (warna merah) dengan 4 persamaan scatter yaitu Linear, Exponential, Logarithmic, dan Power maka telah didapat nilai derajat determinasi $\mathrm{R}^{2}$ yang dapat dilihat pada Tabel 3, Tabel 4, dan Tabel 5.

Tabel 3 Resume Model Matematis dengan Nilai R ${ }^{2}$ untuk Rrs_412 nm

\begin{tabular}{cccc}
\hline No & Algoritma & Model Matematis & $\mathbf{R}^{2}$ \\
\hline 1 & Linier & TDS $(\mathrm{mg} / \mathrm{l})=508860 \mathrm{x}+3638,8$ & 0,0804 \\
2 & Eksponensial & $\operatorname{TDS}(\mathrm{mg} / \mathrm{l})=3428 \mathrm{e}^{117,31 \mathrm{x}}$ & 0,1052 \\
3 & Logaritmik & $\mathrm{TDS}(\mathrm{mg} / \mathrm{l})=508860 \mathrm{x}+3638,8$ & 0,1125 \\
4 & Power & $\mathrm{TDS}(\mathrm{mg} / \mathrm{l})=37328 \mathrm{x}^{0,3468}$ & 0,1476 \\
\hline
\end{tabular}

Tabel 4 Resume Model Matematis dengan Nilai $\mathrm{R}^{2}$ untuk Rrs_531 nm

\begin{tabular}{cccc}
\hline No & Algoritma & Model Matematis & $\mathbf{R}^{2}$ \\
\hline 1 & Linier & $\mathrm{y}=-1 \mathrm{E}+06 \mathrm{x}+11412$ & 0,3933 \\
2 & Eksponensial & $\mathrm{y}=15352 \mathrm{e}^{-214,8 \mathrm{x}}$ & 0,3229 \\
3 & Logaritmik & $\mathrm{y}=-6344 \ln (\mathrm{x})-28159$ & 0,4084 \\
4 & Power & $\mathrm{y}=11,098 \mathrm{x}^{-1,16}$ & 0,3362 \\
\hline
\end{tabular}

Tabel 5 Resume Model Matematis dengan Nilai R² untuk Rrs_667 nm

\begin{tabular}{cccc}
\hline No & Algoritma & Model Matematis & $\mathbf{R}^{2}$ \\
\hline 1 & Linier & $\operatorname{TDS}(\mathrm{mg} / \mathrm{l})=-2.10^{6} \mathrm{x}+7344,4$ & 0,5043 \\
2 & Eksponensial & $\mathrm{TDS}(\mathrm{mg} / \mathrm{l})=7727,5 \mathrm{e}^{-369 \mathrm{x}}$ & 0,5486 \\
3 & Logaritmik & $\mathrm{TDS}(\mathrm{mg} / \mathrm{l})=-2548 \ln (\mathrm{x})-12260$ & 0,6101 \\
4 & Power & $\mathrm{TDS}(\mathrm{mg} / \mathrm{l})=145,86 \mathrm{x}^{-0,514}$ & 0,6109 \\
\hline
\end{tabular}


Dari hasil perhitungan pada Tabel 3 untuk panjang gelombang $412 \mathrm{~nm}$, Tabel 4 untuk panjang gelombang $531 \mathrm{~nm}$ dan Tabel 5 untuk panjang gelombang $667 \mathrm{~nm}$ dapat diketahui bahwa panjang gelombang yang memiliki nilai $\mathrm{R}^{2}$ atau derajat determinasi terbesar adalah Tabel 5. Panjang gelombang $667 \mathrm{~nm}$ dengan Model Logarithmic yang nantinya akan digunakan untuk pemetaan citra satelit Terra MODIS.

Tabel 6 Hasil T-test Data Insitu dan Data Citra Terra MODIS

\begin{tabular}{cccc}
\hline & TDS Insitu & TDS Citra & Keterangan \\
\hline Mean & 5446.67 & 5448.00 & Rata-Rata \\
Variance & 2431509.52 & 1433997.16 & Perbedaan \\
Observations & 15.00 & 15.00 & Pengamatan \\
Pearson Correlation & 0.77 & & Hubungan \\
$d f$ & 14.00 & & Derajat Kebebasan \\
$t$ Stat & -0.01 & & T Hitung \\
$P(T<=t)$ one-tail & 0.50 & & \\
$t$ Critical one-tail & 1.76 & & \\
$P(T<=t)$ two-tail & 1.00 & & T Tabel \\
$t$ Critical two-tail & 2.14 & &
\end{tabular}

Sumber : Hasil Olah Data

Dari Uji T diketahui korelasi Pearson > 77\% atau 0.77 dan juga $\mathrm{T}$ hitung $<\mathrm{T}$ Tabel yang menunjukan tidak adanya perbedaan yang signifikan. Persamaan Logarithmic pada Rrs_667 nm dapat digunakan untuk penelitian selanjutnya untuk menghitung kadar TDS.

\subsection{Pemetaan Sebaran Total Dissolved Solid (TDS)}

Dari hasil perhitungan dan analisa menunjukkan bahwa data yang diambil langsung (insitu) dan data yang dihitung dari citra satelit Terra Modis ada perbedaan namun tidak signifikan sehingga masih dapat diterima. Kemudian data tersebut dipetakan dengan cara memasukkan hasil algoritma terbesar yaitu Logarithmic pada panjang gelombang Rrs $667 \mathrm{~nm}$ ke Math Band di SeaDAS sehingga didapatkan Peta Sebaran Padatan Terlarut yang akan ditunjukkan pada Gambar 16. 


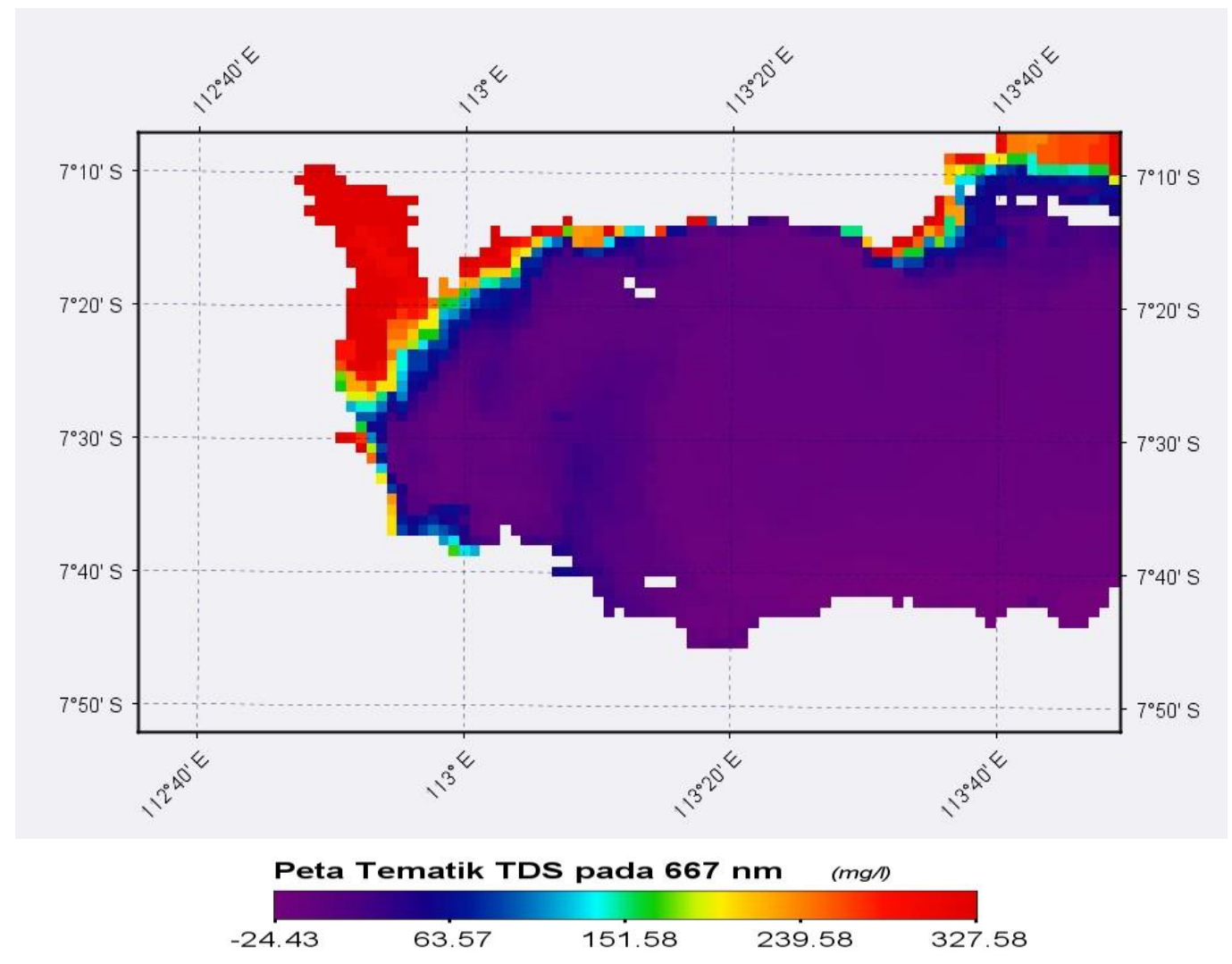

Gambar 7 Peta Sebaran Padatan Terlarut (TDS) dalam mg/l

\section{KESIMPULAN}

Berikut adalah beberapa kesimpulan dari penelitian ini.

1. Hasil perhitungan padatan terlarut citra satelit Terra MODIS yang memiliki hasil yang mendekati dari padatan terlarut in situ adalah algoritma Logarithmic pada panjang gelombang Rrs $667 \mathrm{~nm}$ dengan model algoritma TDS(mg/l) $=-2548 \ln (\mathrm{x})-$ 12260 dan dengan derajat determinasi $\mathrm{R}^{2}=0,610$.

2. Nilai konsentrasi sebaran padatan terlarut di pesisir pantai Pasuruan dapat disimpulkan bahwa nilai konsentrasi tertinggi ada di titik pengambilan sampel ke-17 dengan koordinat $7^{\circ} 35^{\prime} 30^{\prime \prime} \mathrm{S}$ lintang selatan $113^{\circ} 2^{\prime} 33^{\prime \prime} \mathrm{E}$ bujur timur yang nilai padatan terlarutnya $7890 \mathrm{mg} / \mathrm{l}$ sedangkan nilai konsentrasi terendah ada titik pengambilan sampel ke-3 dengan koordinat $7^{\circ} 38^{\prime} 40^{\prime \prime} \mathrm{S}$ lintang selatan $113^{\circ} 4^{\prime} 28^{\prime \prime} \mathrm{E}$ bujur timur yang nilai padatan terlarutnya $3340 \mathrm{mg} / \mathrm{l}$. Nilai rata-rata konsentrasi dari seluruh titik pengamatan adalah $5581.5 \mathrm{mg} / \mathrm{l}$.

3. Peta Tematik Padatan Terlarut Pesisir Pantai Pasuruan telah ditunjukkan pada Gambar 16. Dari peta tersebut ada beberapa kawasan yang perlu diperhatikan jika akan membangun bangunan pantai/ Off shore yaitu $7^{\circ} 42^{\prime} 00^{\prime \prime} \mathrm{S}-7^{\circ} 46^{\prime} 00^{\prime \prime S}$ lintang 
selatan $113^{\circ} 14^{\prime} 00^{\prime \prime} \mathrm{E}-113^{\circ} 18^{\prime} 00^{\prime \prime} \mathrm{E}$ bujur timur dan $7^{\circ} 39^{\prime} 00^{\prime \prime} \mathrm{S}-7^{\circ} 42^{\prime} 00^{\prime \prime S}$ lintang selatan $113^{\circ} 20^{\prime} 00^{\prime \prime} \mathrm{E}-113^{\circ} 26^{\prime} 00^{\prime \prime} \mathrm{E}$ bujur timur dikarenakan dua kawasan tersebut memiliki warna merah yang pekat dengan arti kadar padatan terlarut yang sangat tinggi. Kadar padatan terlarut yang terlalu tinggi cenderung terjadinya sedimentasi di daerah tersebut dan tiap tahunnya akan semakin bertambah sedimennya.

\section{Ucapan Terima Kasih}

Penulis ingin mengucapkan terima kasih kepada segenap teman-teman yang membantu dalam pengambilan data lapangan, serta Prodi Teknik Sipil yang meminjamkan laboratorium Komputer dan Sistem Informasi Geografis untuk pengolahan data, TU Fakultas dan LPPM UPN Veteran Jatim atas bantuan pelayanan administrasinya.

\section{DAFTAR PUSTAKA}

Bilotta, G. S., \& Brazier, R. E. (2008). Understanding the Influence of Suspended Solids on Water Quality and Aquatic Biota. https://doi.org/10.1016/j.watres.2008.03.018

Brando, V., Dekker, A., Marks, A., Qin, Y., \& Oubelkheir, K. (2006). Chlorophyll and Suspended Sediment Assessment in a Macrotidal Tropical Estuary Adjacent to the Great Barrier Reef: Spatial and Temporal Assessment Using Remote Sensing. Cooperative Research Centre for Coastal Zone, Estuary \& Waterway Management - Technical Report $74,1-128$.

Carlson, D. (2014). Influence of Land Use on Total Suspended Solid and Dissolved Ion Concentrations: Baton Rouge, Louisiana area. IAHS-AISH Proceedings and Reports, 367(December 2014), 258-264. https://doi.org/10.5194/piahs-367-258-2015

Crisci, C., Terra, R., Pacheco, J. P., Ghattas, B., Bidegain, M., Goyenola, G., Lagomarsino, J. J., Méndez, G., \& Mazzeo, N. (2017). Multi-model Approach to Predict Phytoplankton Biomass and Composition Dynamics in a Eutrophic Shallow Lake Governed by Extreme Meteorological Events. Ecological Modelling, 360, 80-93. https://doi.org/10.1016/j.ecolmodel.2017.06.017

Esaias, W. E. (1996). ALGORITHM THEORETICAL BASIS DOCUMENT FOR MODIS PRODUCT MOD-27 OCEAN PRIMARY PRODUCTIVITY (ATBD-MOD-24). https://modis.gsfc.nasa.gov/data/atbd/atbd_mod24.pdf

NASA Goddard Space Flight Center, Ocean Ecology Laboratory, O.B.P.G. (2020). 
Moderate-Resolution Imaging Spectroradiometer (MODIS) Terra (T2020066032000.L2_LAC_OC.nc) Data; NASA OB.DAAC, Greenbelt, MD,USA. NASA OB.DAAC, Greenbelt, MD, USA.

https://doi.org/10.5067/TERRA/MODIS/L2/OC/2020

Ody, A., Doxaran, D., Vanhellemont, Q., Nechad, B., Novoa, S., Many, G., Bourrin, F., Verney, R., Pairaud, I., \& Gentili, B. (2016). Potential of High Spatial and Temporal Ocean Color Satellite Data to Study the Dynamics of Suspended Particles in a Micro-tidal River Plume. Remote Sensing, 8(3). https://doi.org/10.3390/rs8030245

Ratnaningsih, D., Nasution, E. L., Wardhani, N. T., Pitalokasari, O. D., \& Fauzi, R. (n.d.). IOP Conference Series: Earth and Environmental Science Water Pollution Trends in Ciliwung River Based on Water Quality Parameters. https://doi.org/10.1088/17551315/407/1/012006

Wibisana, H., Soekotjo, B. M., \& Lasminto, U. (2019). Preliminary Study of Total Suspended Solid Distribution in Coastal Ujung Pangkah Gresik Based Reflectance Value of Landsat Satellite Imagery. Indonesian Journal of Geography, 51(1), 42-48. https://doi.org/10.22146/IJG.38967

Wibisana, H., \& Zainab, S. (2017). Time Series Analysis of Sea Surface Temperature With Aqua MODIS from 2011 to 2016. Case Studi: North Coast of Gresik and Madura. IPTEK The Journal for Technology and Science, 28(1), 15-19. https://doi.org/10.12962/J20882033.V28I1.2217 